\title{
Antimicrobial effect of a cyclic peptide Nostophycin isolated from wastewater cyanobacteria, Nostoc calcicola
}

\author{
Vaishali Gupta1*, Deepak Vyas ${ }^{2}$ \\ ${ }^{1} G o v e r n m e n t$ College, Bichhua, Dist. Chhindwara, Madhya Pradesh 480111, India, ${ }^{2}$ Department of Botany, Dr. Hari \\ Singh Gour Central University, Sagar, Madhya Pradesh 470003, India
}

Received: December 03, 2020

Revised: April 12, 2021

Accepted: April 15, 2021

Published: April 29, 2021

\section{ABSTRACT}

Different types of peptides are produced by cyanobacteria of the genus Nostoc, which are unique in structure and have a wide spectrum of biological activities. The objective of the study is to explore different habitats of organism and study antimicrobial activities to improve their pharmaceutical application and drug like properties by structure modification. A cyclic peptide nostophycin was isolated from Nostoc calcicola (MK506349) through freeze dried lyophilization method. Its structure has been elucidated using FT-IR, ${ }^{1} \mathrm{HNMR},{ }^{13} \mathrm{CNMR}$ and LC-MS. Glycine, d-glutamine, l-phenylamine, d-isoleucine, 1-proline and a novel amino acid Ahoa are constituents of nostophycin. ${ }^{1} \mathrm{HNMR},{ }^{13} \mathrm{CNMR}$ spectroscopy confirmed the number of protons and carbons, and characteristics peak determined the structure and fragmentation pattern through LC-MS. Nostophycin possess Ahoa instead of Adha which makes it different from microcystin. Nostophycin exhibits antimicrobial activity against E.coli, S. aureus, C. albicans and A. niger. Significant antifungal activity $(9-52 \mu g / \mathrm{mL})$ and moderate antibacterial activity (concentration 18-52 $\mu \mathrm{g} / \mathrm{mL}$ ) were observed for nostophycin. In case of already known

*Corresponding Author:

Vaishali Gupta,

*E-mail: vaishaligupta28@

gmail.com peptides, these molecules may be further exploited to improve pharmaceutical application and future drug development.

KEYWords: Ahoa, Cyclic Peptide, ${ }^{1}$ HNMR, ${ }^{13} \mathrm{CNMR}$, LC-MS and Microcystine.

\section{INTRODUCTION}

Cyanobacterial features conspicuous researchers due to their capability of synthesis of various bioactive compounds, diverse range of habitats, wide diversity and morphological variability. Cyanobacteria are gram negative, photosynthetic and ubiquitous bacteria, which known as a primary producer (Gademann \& Portmann, 2008). Availability in the extreme environment and unique feature of cyanobacteria, considered it to be future pioneer for research (Kulasooriya, 2011; Potts, 1999; Scherer et al., 1988; Scherer \& Potts, 1989). According to Kalaitzis et al. (2009) cyanobacteria can produce immense range of bioactive compounds which help in survival in endurance and competitive ecological niche. Bioactive metabolites synthesized by Nostoc sp has been applied as a biofertilizer (Ghazal et al., 2018; Win et al., 2018), anticancer (Moore, 1996), antifungal (El-Sheekh et al., 2014), antibacterial (Ploutno \& Carmeli, 2000), antiviral (Botos \& Wlodawer, 2003) and enzyme-inhibiting (MazurMarzec et al., 2018). These bioactive compounds are explored and identified as peptides, alkaloids, terpenoids, fatty acid and lipopolysaccharides (Chorus, 2012; Dembitsky \& Řezanka, 2005; Dittmann et al., 2001; Nowruzi et al., 2012; Parmar et al., 2011). Allelochemicals influence their own growth potential, other microbes in their vicinity, associated microorganisms, higher plants and animals. Cyanobacteria synthesize nitrogen storage material, new proteins, change pigmentation, excrete and store some other compounds, in response to environmental stress, temperature, $\mathrm{pH}$, nutrient availability and light intensity (Mendes \& Vermelho, 2013; Priya et al., 2015; Singh, 2014).

High number of metabolites, lipid and lipid like compounds, peptides, oligopeptides and amino acid derivatives produced by different genera of the Nostocaceae family (Řezanka \& Dembitsky, 2006). Nostocyclamide a macrocyclic peptide was first reported in Nostoc sp. (Jüttner et al., 2001) and Nostophycin has been isolated from Nostoc calcicola, cyclic peptide with different amino acid including unusual amino acid (Fewer et al., 2011). Extracts from various cyanobacteria have already been proved beneficial for Triticum aestivum (Jäger et al., 2005) Oryza sativa (Saadatnia \& Riahi, 2009), Zea mays (Saadatnia \& Riahi, 2009), Cucumis sativus, Cucurbita maxima and Solanum lycopersicum (Shariatmadari et al., 2011). Cyanobacteria are known to produce different allelochemicals that have the potential for multiple usages in various fields. Drug-like properties of peptide, combine effect of compounds, pharmaceutical applications of peptides can be improved and

Copyright: (C) The authors. This article is open access and licensed under the terms of the Creative Commons Attribution License (http://creativecommons.org/licenses/by/4.0/) which permits unrestricted, use, distribution and reproduction in any medium, or format for any purpose, even commercially provided the work is properly cited. Attribution — You must give appropriate credit, provide a link to the license, and indicate if changes were made. 
explored widely. The aim of the present work was to elucidate the chemical structure of extracted compound of Nostoc calcicola and examine its antibacterial and antifungal potential.

\section{MATERIALS AND METHODS}

\section{Isolation and Identification of Cyanobacteria}

Samples were collected from waste water of catchment area of Banjara Lake of Sagar, Madhya Pradesh, India, situated between $23.83^{\circ}$ North latitude and $78.73^{\circ}$ East longitude and unialagal culture was obtained by streak plate method. Nostoc calcicola were cultured in BG 11 medium, pH 6.5 at temperature $25 \pm 2^{\circ} \mathrm{C}$, light intensity 2500-3000 lux for 14 h light/10 h dark (Rippka et al., 1981). Morphological identification of cyanobacterium was done by microscopic analysis (Micron 36620, Carl Zeiss, Germany) using the keys and description of treaties of Desikachary (1959). Total genomic DNA extraction and 16S rRNA gene amplification were done with standard methodology. The sequence for the species was deposited to the prokaryotic rRNA submission portal of GenBank and the accession number was obtained.

\section{Mass Culture and Crude Extract From Cyanobacterial Samples}

Cells were harvested in mid log phase and centrifuged at $10000 \times \mathrm{g}$ for $15 \mathrm{~min}$ and supernatant was removed and pellet was lyophilized (freeze dried) for $12 \mathrm{~h}$. Furthermore, freeze dried pellet was suspended in methanol and 0.01\% TFA (Trifluoroacetic acid), then shaken for 8 h by orbital shaker. Later, it was kept overnight at $-20{ }^{\circ} \mathrm{C}$ and further sonicated in a cold room. Subsequently, centrifuged at $10000 \times$ g for 15 minute and supernatant was vacuum dried at $40^{\circ} \mathrm{C}$ and pellet was re-extracted twice. The mixture was stored in glass vials at $-4^{\circ} \mathrm{C}$. Yield percentage of extract was calculated by following formula, Yield \% = Weight of evaporated extract/ Weight of cyanobacterial powder $\times 100$

\section{SPECTRAL ANALYSIS}

Spectral analysis was carried out by freeze dried extracts namely, Nostoc calcicola using standard procedures to identify the components.

\section{Fourier Transform Infrared (FTIR) Spectroscopy}

Fourier transform infrared spectroscopy (FTIR) performed on Shimadzu 8400S. The spectrum of solid sample was obtained using $\mathrm{KBr}$ (Potassium bromide) pellets. About $1 \mathrm{mg}$ of sample and $100 \mathrm{mg}$ of $\mathrm{KBr}$ were ground together, dried to remove moisture and mechanically placed in sample holder. The $\mathrm{KBr}$ does not absorb infrared radiation in the region $4000 \mathrm{~cm}^{-1}$ and $500 \mathrm{~cm}^{-1}$ and complete spectrum of the solid sample is obtained (Sharma, 1981).

\section{Nuclear Magnetic Resonance Spectroscopy (NMR)}

${ }^{1} \mathrm{H}$ NMR and ${ }^{13} \mathrm{C}$ NMR spectroscopies were performed by BrukerAvance II at $500 \mathrm{MHz}$, Advanced Instrumentation
Research Facility (AIRF), Jawahar Lal Nehru University, New Delhi using DMSO as a solvent.

\section{Liquid Chromatography- Mass Spectrometry (LC-MS)}

LC-MS is sophisticated technique used for separation or purification of sample followed by fragmentation pattern. LCMS analysis was carried out at Indian Institute of Science and Research (IISER) Bhopal, by Agilent technologies 1260 infinity and Agilent technologies 6130 quadrupole. Methanol was used as a solvent for LC-MS. Standard of amino acids were used as control for control in NMR and LCMS.

\section{Bacterial Strain Preparation}

The bacterial strain Escherichia coli MTCC\#1591 (E. coli), Staphylococcus aureus MTCC\#3212 (S. aureus) and fungi strains Aspergillus niger MTCC\#9652 (A. niger), Candida albicans (MTCC\# 183) were obtained from The Microbial Type Culture Collection and Gene Bank (MTCC) Chandigarh, India. The test bacteria were maintained in nutrient broth media while the test fungi were maintained on potato dextrose agar plates. The test organisms were subcultured 2-8 h before the test.

\section{Preparation of Resazurin Solution}

The resazurin solution was prepared at $0.02 \%$ (wt/vol) with 0.002 $\mathrm{g}$ of resazurin salt powder was dissolved in $10 \mathrm{~mL}$ of distilled water and vortexed. The mixture was filtered by Millipore membrane filter $(0.2 \mu \mathrm{m})$. The resazurin solution can be kept at $4^{\circ} \mathrm{C}$ for 2 weeks.

\section{Disk Diffusion Method}

The antibacterial activity of extracted sample against the procured test bacteria was carried out using Kirby-Bauer Disk Diffusion susceptibility Test Method (Hudzicki, 2009). The bacterial strains were spread on Mueller-Hinton agar (Merck, Germany) using sterile cotton swab. Extracted sample was prepared at concentrations of $0.2,0.4,0.6,0.8$ and $1 \mathrm{mg} / \mathrm{ml}$. Sterile blank antimicrobial disk was used in the test. The disks were loaded aliquot $5 \mathrm{~mL}$ with different concentrations of sample and ampicillin and miconazole was used as positive control for bacteria and fungi respectively, while methanol as a negative control.

For antifungal test, Mueller-Hinton agar supplemented with 2\% glucose and $0.5 \mu \mathrm{g} / \mathrm{ml}$ methylene blue was used as a medium. The inoculated plates were incubated at $37{ }^{\circ} \mathrm{C}$ for $24-48 \mathrm{~h}$ and the diameter of the inhibition zone was measured after incubation. All the tests were performed in three replicates, and mean of inhibition zone was calculated.

\section{Determination of Minimum Inhibitory Concentration}

Minimum inhibitory concentration (MIC) was determined by using the method described in standard CLSI guidelines (Wayne, 2012). The MIC test was performed in 96 well round 
bottom microtiter plate using standard broth microdilution method while MBC was performed on the MHA plates. The bacterial inoculums were adjusted to the concentration of $10^{6} \mathrm{CFU} / \mathrm{mL}$. For the MIC test, five dilutions were prepared with $4.5,6.5,8.5,10.5$ and $12.5 \mathrm{mg} / \mathrm{mL}$ extracted sample in methanol. A total of $50 \mu \mathrm{L}$ of the microbial suspension, at 0.5 McFarland concentrations, was inoculated into each well and then the microtiter plate was incubated at $37^{\circ} \mathrm{C}$ for $24 \mathrm{~h}$. The lowest concentration at which no turbidity was observed was considered the MIC. A well of the microtiter plate with no microorganisms was considered as the negative control and with no extract was considered as the positive control.

The MBC was defined as the lowest concentration of the antibacterial agents that completely kill the bacteria. MBC test performed by plating the suspension from well of microtiter plates into MHA plates. The plates were incubated at $37^{\circ} \mathrm{C}$ for $24 \mathrm{~h}$. The lowest with no visible growths on the MHA plate was taken as $\mathrm{MBC}$ value.

\section{Time-kill Curve}

Time-kill assay was done in MHB medium as described by Zainin et al. (2013) and Lau et al. (2018). The bacterial inoculums were adjusted to $10^{6} \mathrm{CFU} / \mathrm{mL}$. The nostophycin solution was diluted with $\mathrm{MHB}$ media containing bacterial inoculums to obtain the final concentration of $0 \times \mathrm{MIC}, 1 \times \mathrm{MIC}, 2 \times \mathrm{MIC}, 4 \times \mathrm{MIC}$, and $8 \times$ MIC for each type of bacteria in the total final volume of $1 \mathrm{~mL}$. The cultures were then incubated at $37^{\circ} \mathrm{C}$ with 150 rpm agitation. The culture $(100 \mu \mathrm{L})$ was spread on MHA plates at time $0,0.25,0.5,1.2$ and $4 \mathrm{~h}$ in triplicates. The number of colonies on the MHA plates was quantified in $\mathrm{CFU} / \mathrm{mL}$ after incubation at $37^{\circ} \mathrm{C}$ for $24 \mathrm{~h}$. For statistical analysis, SPSS (v.26) statistical package was used to determine the significant $(\mathrm{P}<0.05)$ difference among the tested bacteria.

\section{DATA ANALYSIS}

The data are presented as mean \pm standard deviation for inhibition zones. For statistical analysis, unpaired t-test was used using SPSS version 26.

\section{RESULT AND DISCUSSION}

With the help of microscopic study and camera lucida sketching, morphological characteristics i.e. subspherical heterocyst, barrel shaped cells, and molecular study confirmed it as Nostoc calcicola (MK506349) (Figure 1).

\section{SPECTRAL ANALYSIS OF NOSTOC CALCICOLA (NPC) EXTRACTED SAMPLE}

\section{FTIR Study}

FTIR spectrum was recorded using $\mathrm{KBr}$ pellets in range 4000$500 \mathrm{~cm}^{-1}$. The FTIR spectrum of the extract shows various stretching bands, hence characteristics bands were analyzed. Total 6 functional groups were detected at the wave range of
$3545,3250,2895,1745,1550$ and $1195 \mathrm{~cm}^{-1}$. The characteristic stretching frequency for carbonyl group attributed to the presence of amide group in sample. Based on the previous literature and standard protocol, the functional classes were characterized as $-\mathrm{OH}$ stretching, $\mathrm{N}-\mathrm{H}$ bond of amine, $-\mathrm{C}-\mathrm{H}$ stretching carbonyl, $\mathrm{C}=\mathrm{C}$ (aromatic ring) stretching and $\mathrm{C}-\mathrm{N}$ stretching respectively (Table 1 ; Figure 2)

\section{NMR Study}

After confirming the presence of carbonyl group in the form of amide group, sample was further characterized by using ${ }^{1} \mathrm{H}$ NMR and ${ }^{13} \mathrm{C}$ NMR spectroscopic techniques. According to literature survey it was noted that the sample consists of peptide bonds (Fujii et al., 1999). The expected structure of sample was further

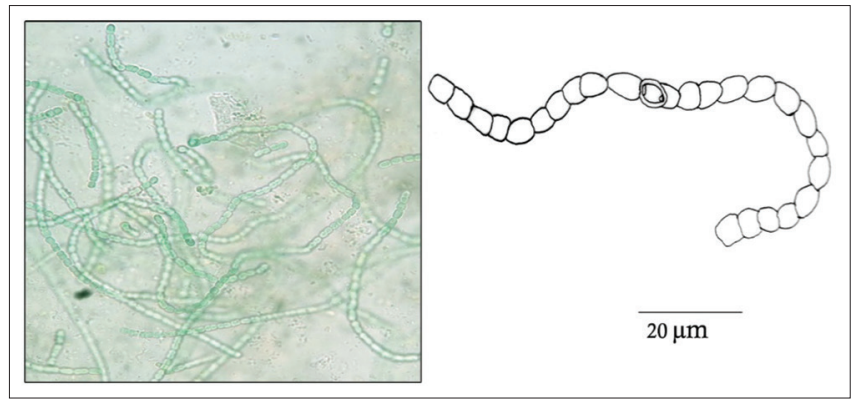

Figure 1: Photomicrograph and camera lucida sketch illustrating the morphological features of isolated Nostoc calcicola (MK506349). Bar denotes $20 \mu \mathrm{m}$

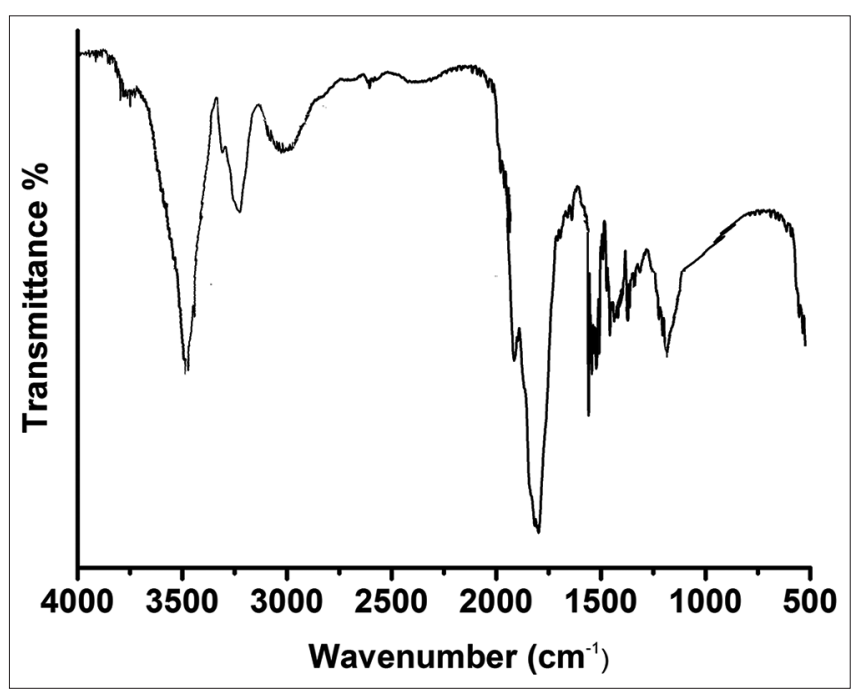

Figure 2: Characteristics IR peaks of NPC

Table 1: Characteristics IR frequencies for NPC.

\begin{tabular}{lcll}
\hline Serial No. & Frequency $\left(\mathrm{cm}^{-1}\right)$ & Functional Group & Type of Vibration \\
\hline 1 & 1745 & $\mathrm{C}=0$ & Stretching \\
2 & 3250 & $\mathrm{~N}-\mathrm{H}$ & Stretching \\
3 & 2895 & $\mathrm{C}-\mathrm{H}$ & Stretching \\
4 & 3545 & $\mathrm{O}-\mathrm{H}$ & Stretching \\
5 & 1550 & $\mathrm{C}=\mathrm{C}$ (Aromatic ring) & Stretching \\
6 & 1195 & $\mathrm{C}-\mathrm{N}$ & Stretching \\
\hline
\end{tabular}


confirmed by the presence of different types of hydrogen atoms present in it. As the literature reports that the whole structure of sample is constructed with different types of amino acids. The set of amino acids as follows proline I, isoleucine, phenylalanine, proline II, glycine and glutamine. The presence of all amino acids and formation of particular peptide bond were taken into consideration. The obtained ${ }^{~} \mathrm{H}$ NMR spectrum for sample was compared with ${ }^{1} \mathrm{H}$ NMR spectra of individual amino acids. The change in chemical shift value of $-\mathrm{NH}_{2}$ in all amino acids were observed. The chemical shift values obtained in range 6-8 $\delta \mathrm{ppm}$ corresponds to proton present in amino acid in the form of -NH in Nostophycin molecule. The compared values suggest that the signals obtained for amino acids in sample shows larger chemical shift value ( $\delta \mathrm{ppm})$ as compared to spectrum obtained for pure amino acids, it may happen due to removal of proton and formation of hydrogen atom (Figure 3).

Some remarkable changes can be mention; the original spectrum of isoleucine displays sharp singlet around 7.05 8ppm but in present sample it shows some shift towards higher chemical shift value $7.37 \delta \mathrm{ppm}$ as doublet with $J=8.4 \mathrm{~Hz}$. Furthermore, phenylalanine and glycine also exhibit the same behavior and their chemical shift values are around 7.39 and $6.89 \delta \mathrm{ppm}$ respectively due to removal of one proton and formation of new bond. Presence of glutamine was confirmed by singlet obtained at $8.7 \delta \mathrm{ppm}$ corresponds to $-\mathrm{N}-\mathrm{H}$ proton whereas singlet at $6.60 \delta \mathrm{ppm}$ value corresponds to $-\mathrm{NH}_{2}$ bond. Additionally one unusual amino acid is determined to be a $\beta$-amino acid (3 amino-2,5-dihydroxy-8-phenyloctanoic acid) or (Ahoa), which exhibits two hydroxyl groups in its structure. The ${ }^{1}$ HNMR spectrum shows following chemical shifts values 5.76 and 7.52 Sppm corresponds to $-\mathrm{OH}$ and $-\mathrm{NH}$ proton respectively. The chemical shift value obtained around $3.62 \mathrm{Spm}(J=8.72)$ can be assigned to protons of $-\mathrm{CH}_{2}$ present in proline amino acid.

The ${ }^{13} \mathrm{C}$ NMR spectrum of sample shows the presence of carbonyl group in structure. The carbonyl group displays its characteristic $\delta p p m$ value around 168-170 $\delta \mathrm{ppm}$. In this context ${ }^{13} \mathrm{C}$ NMR spectrum obtained for sample are in two different ranges. Figure 4 displays characteristics peaks for different types of carbonyl group present in compound. The chemical shift values obtained at 171.1, 170.5 and 168.1 Sppm assigned for carbonyl group present in proline, isoleucine and glycine molecule. The singlet obtained for each carbonyl group suggests that no direct proton is attached to the carbon atom. The other singlets obtained at 170.1, 174.2 and 175.2 corresponds to carbonyl group present in glutamine, phenylalanine and 2,5-dihydroxy-8-phenyloctanoic acid.

\section{Liquid Chromatography- Mass Spectrometry (LC-MS) Study}

As, it is important to confirm the molecular mass of sample, LCMS technique was applied to confirm the established structure of sample. Therefore, a confirmation of the amino acids spectra and structure of cyanobacterial peptides by LC-MS at $1000 \mathrm{~m} / \mathrm{z}$ was carried out (Fujii et al., 1999).

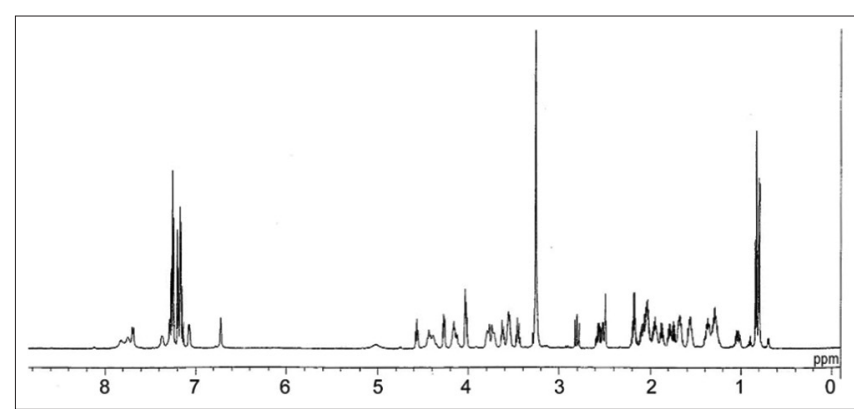

Figure 3: Typical ${ }^{1} \mathrm{H}$ NMR spectrum of NPC at $500 \mathrm{MHZ}$ in DMSO-d6

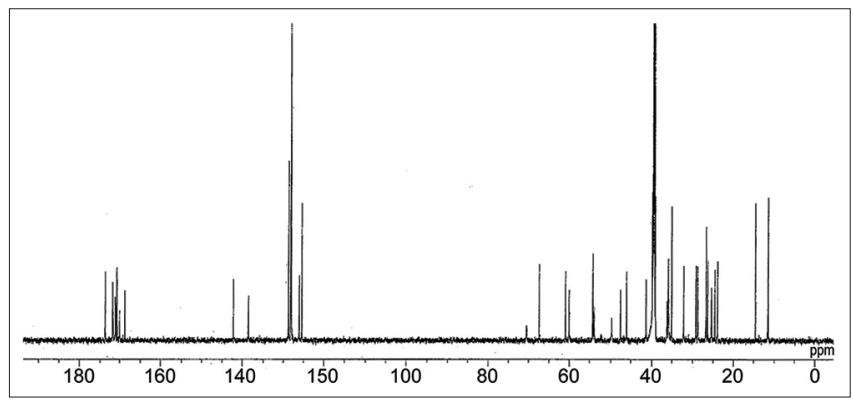

Figure 4: Typical ${ }^{13} \mathrm{CNMR}$ spectrum of NPC at $500 \mathrm{MHZ}$ in DMSO-d6

In the product ion spectrum (Figure 5) for the $[\mathrm{M}+\mathrm{H}]^{+}$at $\mathrm{m} / \mathrm{z} 889$ of sample, several ions were prominently observed, which were assigned as the ions of each constituent amino acid residue lost from the precursor ion $[\mathrm{M}-G l y i n e]^{+}$at $m / z 833$, [M -Isoleucine] $]^{+}$at $\mathrm{m} / \mathrm{z} 775$ and [M-Phenyalanine] ${ }^{+}$at $\mathrm{m} / \mathrm{z}$ 74l, [M-3-amino- 2,5-dihydroxy-8-phenyloctanoic acid (Ahoa) and

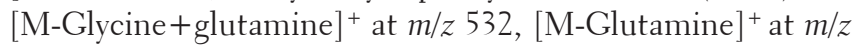
744.

\section{STRUCTURE ELUCIDATION}

Based on the results of FT-IR, NMR $\left({ }^{13} \mathrm{C}\right.$ and $\left.{ }^{1} \mathrm{H}\right)$ and mass spectroscopy the molecule was tentatively predicted as cyclic peptide and the structure is composed of six amino acids and a novel $\beta$-Ahoa; named as Nostophycin. Molecular formula of the nostophycin was $\mathrm{C}_{46} \mathrm{H}_{62} \mathrm{~N}_{8} \mathrm{O}_{10}$ and molecular weight was predicted as 887. The structure was shown in Figure 6.

\section{Antimicrobial activity of Nostophycin}

The antibacterial activity of nostophycin was determined against two bacterial (E. coli and S. aureus) and two fungal species (A. niger and C. albicans). The results for disk diffusion test, MIC and MBC of the nostophycin are summarized in Table 2. For the disk diffusion test, the presence of clear zone around the nostophycin disk suggesting that the nostophycin possessed antimicrobial activity which is able to inhibit the growth of bacteria and fungus. As previous study reported that nostophycin extracted from Nostoc CCC537 produced a maximum inhibition zone $(29 \mathrm{~mm})$ for $S$. aureus followed by P. aeruginosa (11 mm), S. typhi $(10 \mathrm{~mm})$, E.coli $(10 \mathrm{~mm})$ and Enterobacter aerogens $(7 \mathrm{~mm})$, it has also been reported that doubling in the concentration increased the inhibition zone for 


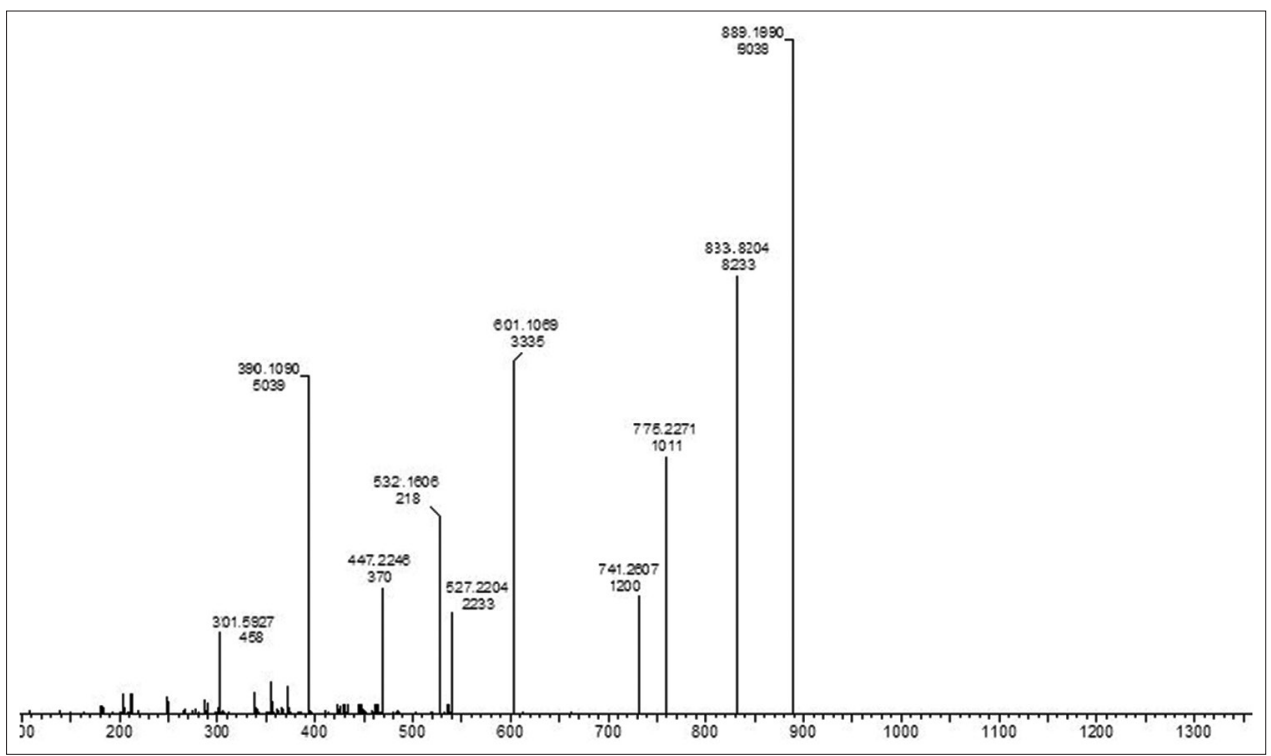

Figure 5: Partially purified molecule analyzed by LC-MS chromatograms at m/z 889 for Nostophycin (NPC) in Methanol

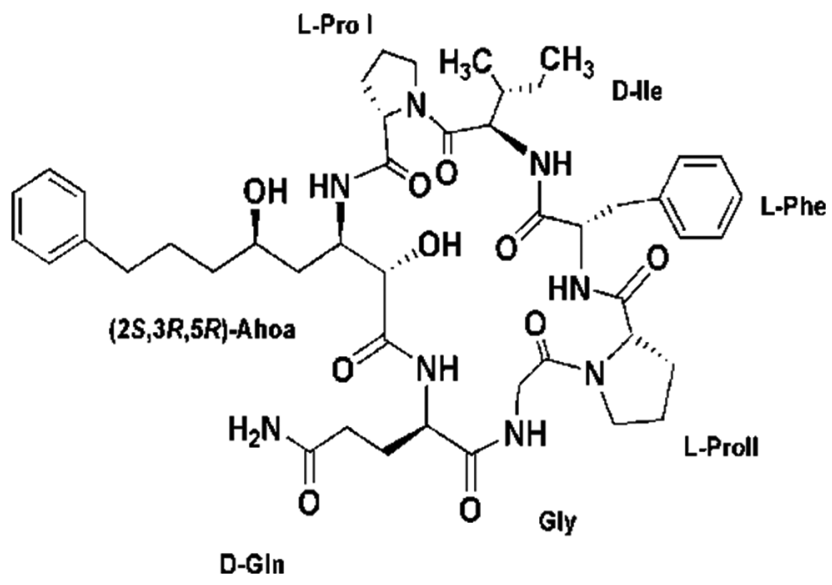

Figure 6: Proposed chemical structure of Nostophycin (NPC) by Nostoc calcicola (MK506349) formula $\mathrm{C}_{46} \mathrm{H}_{62} \mathrm{~N}_{8} \mathrm{O}_{10}$ and molecular weight 887

the same microorganism (Asthana et al., 2009). Agrawal (2016) also reported antibacterial and antifungal activity of extract of $N$. calcicola against different human pathogens through inhibition zone ranging from 7.5 to $20 \mathrm{~mm}$.

Disk diffusion test was described as the preliminary study in screening the antibacterial activity of an antimicrobial agent; therefore, a further evaluation in determining the antibacterial activity of nostophycin using MIC value was needed. MIC was defined as the lowest concentration of the antibacterial agent to inhibit the growth of bacteria by serial dilution. As showed in Table 2, the MIC values of nostophycin against the bacteria and fungi were ranged from 4.5 to $8.5 \mathrm{mg} / \mathrm{mL}$. It has been reported that low concentration of active principle $2.5 \mu \mathrm{g} / \mathrm{mL}$ of Nostoc CCC 537 was effective against M. tuberculosis H37Rv (Asthana et al., 2009). MBC is the lowest concentration of antibacterial and antifungal agent to kill the bacteria and fungus (showed no growth on the agar plate). MBC for Candida albicans (4.5) followed by E.coli and A. niger (6.5) and with maximum for
Table 2: The diameter of inhibition zone $(\mathrm{mm}), \mathrm{MIC}$ value $(\mu \mathrm{g} / \mathrm{mL})$, and $M B C$ value $(\mu \mathrm{g} / \mathrm{mL})$

\begin{tabular}{lccc}
\hline Organisms & $\begin{array}{c}\text { Inhibition Zone } \\
\text { Diameter }(\mathrm{mm})\end{array}$ & $\mathrm{MIC}(\mu \mathrm{g} / \mathrm{mL})$ & $\mathrm{MBC}(\mu \mathrm{g} / \mathrm{mL})$ \\
\hline Escherichia coli & 22 & 4.5 & 6.5 \\
Stayphylococcus aureus & 38 & 6.5 & 8.5 \\
Aspergillus niger & 20 & 6.5 & 6.5 \\
Candida albicans & 24 & 4.5 & 4.5 \\
\hline
\end{tabular}

S. aureus (8.5). It has been reported that lower quantity of active principle of Nostoc CCC 537 is more effective on high quantity of streptomycin and rifampicin against Enterobacter aerogens (Asthana et al., 2009). Pesticidal effects of methanolic extract of Nostoc strain ATCC 53789 from 0.25g/L to 100g/L has been used to treat various pathogenic fungi (Biondi et al., 2004). Resazurin dye was used in the study to determine cell growth, especially in cytotoxicity assays (McNicholl et al., 2007). Oxidoreductase within viable cells reduced the resazurin salt to resorufin and changed the color from blue non-fluorescent to pink and fluorescent. According to McNicholl et al. (2007), resazurin dye has been applied for decades to check for the bacterial and yeast contamination milk.

\section{TIME-KILL CURVE}

The time kill activity of bacteria and fungi is shown in Figure 7. The reduction in the number of $\mathrm{CFU} / \mathrm{mL}$ effective against bacteria and fungi were $\geq 3$ Log units (99\%) for bactericidal and fungicidal activity of nostophycin. The bactericidal endpoint of nostophycin for E. coli was reached after $2 \mathrm{~h}$ of incubation at $4 \times \mathrm{MIC}(18 \mu \mathrm{g} /$ $\mathrm{mL})$ and $8 \times \mathrm{MIC}(36 \mu \mathrm{g} / \mathrm{mL})$, while for Staphylococcus aureus, the bacteria was killed after $2 \mathrm{~h}$ of incubation at $4 \times \mathrm{MIC}(26 \mu \mathrm{g} / \mathrm{mL})$ and $8 \times \mathrm{MIC}(52 \mu \mathrm{g} / \mathrm{mL})$. The fungicidal endpoint of nostophycin for Aspergillus niger was reached after $2 \mathrm{~h}$ of incubation at $4 \times$ MIC $(26 \mu \mathrm{g} / \mathrm{mL})$ and $8 \times \mathrm{MIC}(52 \mu \mathrm{g} / \mathrm{mL})$. Candida albicens was killed after $1 \mathrm{~h}$ of incubation at $2 \times \mathrm{MIC}(9 \mu \mathrm{g} / \mathrm{mL}), 4 \times \mathrm{MIC}$ $(18 \mu \mathrm{g} / \mathrm{mL}), 8 \times \mathrm{MIC}(36 \mu \mathrm{g} / \mathrm{mL})$. 


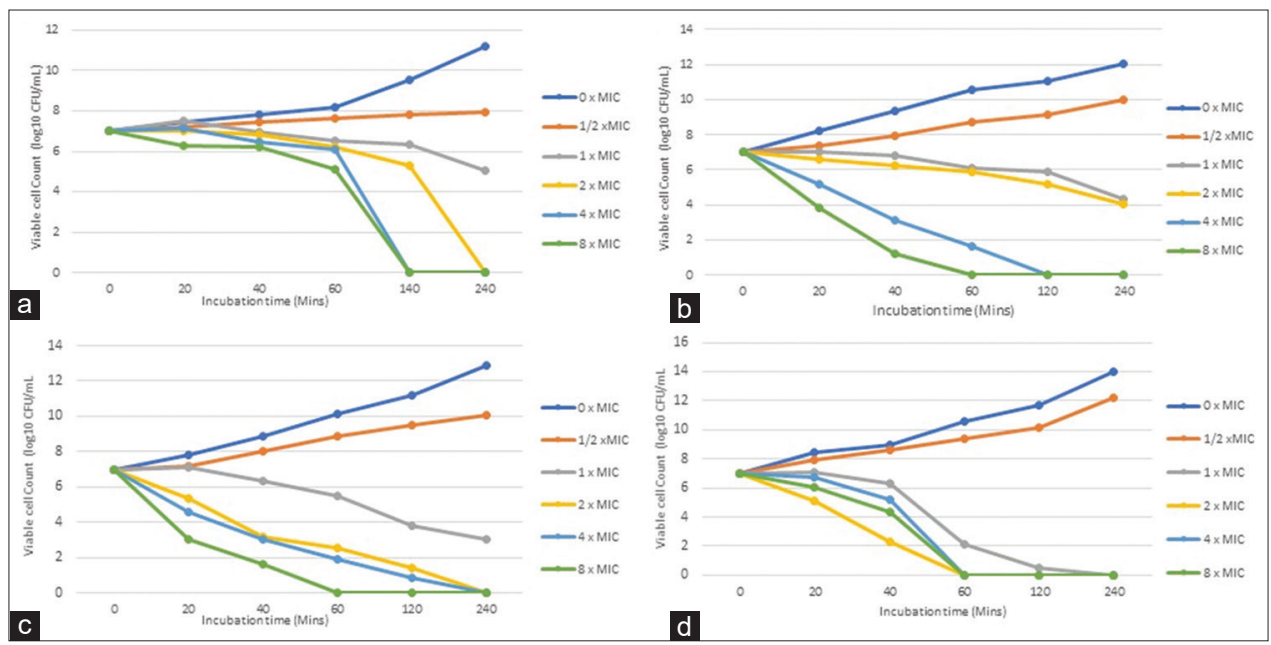

Figure 7: Time-kill plots of Nostophycin against A. E.coli B. S. aureus C. A. niger D. C. albicans

Antibacterial activity of Nostoc sp. is already reported by Asthana et al. (2009), and antifungal activity is reported by Agrawal (2016). Structurally diverse group of Nostophycin exhibits antibacterial activity against gram negative bacteria E.coli and gram positive bacteria $S$. aureus, similarly antifungal activity against A. niger and C. albicans. No significant differences were found between gram positive and negative bacteria, and fungus, which indicates that nostophycin is broad spectrum antimicrobial and antifungal agent. In this study, nostophycin compound extracted from Nostoc calciola include a structurally diverse group i.e. cyclic and linear peptides, phenolics and fatty acid. Different bioactive compounds like nostocine A (Hirata et al., 1996) and tenuecyclamide A- D (Banker \& Carmeli, 1998) from N. spongiaeformae, noscomin (Jaki et al., 1999) and comnostin A-E (Jaki et al., 2000) from N. commune, borophycin (Hemscheidt et al., 1994), muscoride (Nagatsu et al.,1995), cryptophycin (Biondi et al., 2004) and nostocarboline (Becher et al., 2005) from N. linckia, N. muscorum, N. ellipsosporum, Nostoc ATCC 53789 and Nostoc 18-12A respectively have been reported. Methanol as a control was not able to inhibit microbial activity but methanol extracted nostophycin exhibits antimicrobial activity against bacteria, different workers also adopted methanol extracts for evaluating antibacterial activity (Asthana et al., 2009); Jaki et al.,, 2000; Mundt et al., 2001). The inherent capacity to produce specific bioactive compounds from methanolic extract of Nostoc strain ATCC 53789 seems to play an antifungal role against a variety of pathogens of different agricultural importance fungi such as Armillaria sp., Colletotrichum coffeanum, C. trifolii, Fusarium solanii, F. oxysporum f. sp. melonis, Penicillium expansum, Phytophthora cambivora, P. cinnamomi, Rhizoctonia solanii, Rosellinia sp. Sclerotinia sclerotiorum and Verticillium albo-atrum (Biondi et al., 2004). Various Nostoc species behave as an antifungal agent such as extract of N. linkia inhibit the growth of wilt disease causing Fusarium oxysporum f. sp. lycopersici, which help in biological control and better yield for tomato plants (Alwathnani \& Perveen, 2012). Extract of Nostoc commune FA-103, Nostoc endophytum and Nostoc muscurum suppress the effect of Fusarium oxysporum f. sp. lycopersici and soyabean root rot causing Rhizoctonia solanii respectively (Ismail \& Ismail, 2011; Kim \& Kim, 2008).

\section{CONCLUSION}

Cyanobacterial cyclic peptide was isolated and identified from Nostoc calcicola through ${ }^{13} \mathrm{CNMR},{ }^{1} \mathrm{HNMR}$ and LC-MS and named as nostophycin, it contains Gln, Gly, Pro I, Pro II, Phe, Ile and Ahoa. Nostophycin exhibits resemblance with microcystin with all variables except amino acid ADHA ((2S,3S,8S,9S)-3amino-9-methoxy-2,6,8-trimethyl-10-phenyldeca-4,6-dienoic acid), which is replaced by Ahoa ((2S,3R,5R)-3-amino-2,5dihydroxy-8-phenyloctanoic acid). The $\beta$-amino acid Ahoa from nostophycin is structurally quite similar to (Ahda) in scytonemin. Similar $\beta$-amino acids are also reported in several peptides isolated from cyanobacteria. But unusual $\beta$-amino acid Ahoa is only found in nostophycin (Fewer et al., 2011). Cyclic peptides from natural resource exhibits a variety of significant biological profiles. The anti-microbial activity of cyanobacterial secondary metabolites has been reported by many researchers. However, the MIC values from previous study showed a large variation. Therefore, the comparison of the result is difficult as there is no standard method for determination of antimicrobial activity of nostophycin. In this study, nostophycin exhibits a good antimicrobial activity against gram positive and gram negative bacteria and fungi. Lower concentration of nostophycin is able to kill bacteria and fungi in a short time, the reproduction time of bacteria is main cause of infection and treating with nostophycin could be a viable way to prevent infections. Unique structure of nostophycin and a wide spectrum of biological activity shows a remarkable biotechnological potential of the Nostoc. Newly discovered or already known bioactive peptides can be used to improve drug-like properties through structure alteration or conjugation with antibodies or small molecules. It is necessary to explore chemical synthesis, exact mechanism of secondary metabolites against bacteria and fungi and search for new chemicals from cyanobacteria.

\section{ACKNOWLEDGEMENT}

The authors express gratitude to Head, department of Botany, Dr. Hari Singh Gour University, Sagar (M.P.) for providing laboratory facilities. Financial assistance to carry out the study 
through University Grant Commission (UGC) New Delhi to VG is also highly acknowledged.

\section{REFERENCE}

Agrawal, M. K. (2016). Antimicrobial Activity of Nostoc calcicola (Cyanobacteria) isolated from central India against human pathogens. Asian Journal of Pharmaceutics, 10(04), S554-S559. http://dx.doi. org/10.22377/ajp.v10i04.892

Alwathnani, H. A., \& Perveen, K. (2012). Biological control of fusarium wilt of tomato by antagonist fungi and cyanobacteria. African Journal of Biotechnology, 11(5), 1100-1105. http://dx.doi.org/10.5897/ AJB11.3361

Asthana, R. K., Deepali, Tripathi, M. K., Srivastava, A., Singh, A. P., Singh, S. P., Nath, G., Srivastava, R., \& Srivastava, B. S. (2009). Isolation and identification of a new antibacterial entity from the Antarctic cyanobacterium Nostoc CCC 537. J Journal of Applied Phycology, 21(1), 81. https://doi.org/10.1007/s10811-008-9328-2

Banker, R., \& Carmeli, S. (1998). Tenuecyclamides A-D, cyclic hexapeptides from the cyanobacterium Nostoc spongiaeforme var. tenue. Journal of natural products, 61(10), 1248-1251. https://doi.org/10.1021/ np980138

Becher, P. G., Beuchat, J., Gademann, K., \& Jüttner, F. (2005). Nostocarboline: isolation and synthesis of a new cholinesterase inhibitor from Nostoc 78-12A. Journal of natural products, 68(12), 1793-1795. https://doi. org/10.1021/np050312।

Biondi, N., Piccardi, R., Margheri, M. C., Rodolfi, L., Smith, G. D., \& Tredici, M. R. (2004). Evaluation of Nostoc strain ATCC 53789 as a potential source of natural pesticides. Applied and Environmental Microbiology, 70(6), 3313-3320. https://doi. org/10.1128/AEM.70.6.3313-3320.2004

Botos, I., \& Wlodawer, A. (2003). Cyanovirin-N: a sugar-binding antiviral protein with a new twist. Cellular and Molecular Life Sciences, 60(2), 277-287. https://doi.org/10.1007/s000180300023

Chorus, I. (2012). Cyanotoxins: occurrence, causes, consequences: Springer Science \& Business Media.

Dembitsky, V. M., \& Rezanka, T. (2005). Metabolites produced by nitrogenfixing Nostoc species. Folia Microbiologica, 50(5), 363-391. https:// doi.org/10.1007/BF02931419

Desikachary, T. V. (1959). Cyanophyta (Vol. 2): Indian Council of Agricultural Research New Delhi.

Dittmann, E., Neilan, B. \& Börner, T. (2001). Molecular biology of peptide and polyketide biosynthesis in cyanobacteria. Applied Microbiology and Biotechnology, 57, 467-473. https://doi.org/10.1007/s002530100810

El-Sheekh, M. M., Daboor, S. M., Swelim, M. A., \& Mohamed, S. (2014). Production and characterization of antimicrobial active substance from Spirulina platensis. Iranian Journal of Microbiology, 6(2), 112-119.

Fewer, D. P., Osterholm, J., Rouhiainen, L., Jokela, J., Wahlsten, M., \& Sivonen, K. (2011). Nostophycin biosynthesis is directed by a hybrid polyketide synthase-nonribosomal peptide synthetase in the toxic cyanobacterium Nostoc sp. strain 152. Applied and Environmental Microbiology, 77(22), 8034-8040. https://doi. org/10.1128/AEM.05993-11

Fujii, K., Sivonen, K., Kashiwagi, T., Hirayama, K., \& Harada, K-I. (1999). Nostophycin, a novel cyclic peptide from the toxic cyanobacterium Nostoc sp. 152. Journal of Organic Chemistry, 64(16), 5777-5782. https://doi.org/10.1021/jo982306i

Gademann, K., \& Portmann, C. (2008). Secondary metabolites from cyanobacteria: complex structures and powerful bioactivities. Current Organic Chemistry, 12(4), 326-341. https://doi. org/10.2174/138527208783743750

Ghazal, F., Mahdy, E., El-Fattah, M., El-Sadany, A., \& Doha, N. (2018). The use of cyanobacteria as biofertilizer in wheat cultivation under different nitrogen rates. Nature and Science, 16(4):30-35

Hemscheidt, T., Puglisi, M. P., Larsen, L. K., Patterson, G. M. L., Moore, R. E., Rios, J. L., \& Clardy, J. (1994). Structure and biosynthesis of borophycin, a new boeseken complex of boric acid from a marine strain of the blue-green alga Nostoc linckia. Journal of Organic Chemistry, 59(12), 3467-3471. https://doi.org/10.1021/jo00091a042

Hirata, K., Nakagami, H., Takashina, J., Mahmud, T., Kobayashi, M., In, Y., Ishida, T., Miyamoto, K. (1996). Novel violet pigment, nostocine A, an extracellular metabolite from cyanobacterium Nostoc spongiaeforme.
J-global, 7(43), 1513-1519

Hudzicki, J. (2009). Kirby-Bauer disk diffusion susceptibility test protocol. American Society for Microbiology. Washington, DC.

Jäger, K., Ördög, V., \& Barnabás, B. (2005). Effect of cyanobacterial and microalgal biomass on anther culture response of wheat (Triticum aestivum L.). Acta Agronomica Hungarica, 53(1), 99-107. https://doi. org/10.1556/AAgr.53.2005.1.12

Jaki, B., Heilmann, J., \& Sticher, O. (2000). New antibacterial metabolites from the cyanobacterium Nostoc commune (EAWAG 122b). Journal of Natural Products, 63(9), 1283-1285. https://doi.org/10.1021/ np000033s

Jaki, B., Orjala, J., \& Sticher, O. (1999). A novel extracellular diterpenoid with antibacterial activity from the cyanobacterium Nostoc commune. Journal of natural products, 62(3), 502-503. https://doi.org/10.1021/ np980444x

Jüttner, F., Todorova, A. K., Walch, N., \& von Philipsborn, W. (2001). Nostocyclamide M: a cyanobacterial cyclic peptide with allelopathic activity from Nostoc 31. Phytochemistry, 57(4), 613-619. https://doi. org/10.1016/s0031-9422(00)00470-2

Kalaitzis, J. A., Lauro, F. M., \& Neilan, B. A. (2009). Mining cyanobacterial genomes for genes encoding complex biosynthetic pathways. Natural Product Reports, 26(11), 1447-1465. https://doi.org/10.1039/b817074f

Khalifa, R. A., Nasser, M. S., Gomaa, A. A., Osman, N. M., \& Salem, H. M. (2013). Resazurin Microtiter Assay Plate method for detection of susceptibility of multidrug resistant Mycobacterium tuberculosis to second-line anti-tuberculous drugs. Egyptian Journal of Chest Diseases and Tuberculosis, 62(2), 241-247. https://doi.org/10.1016/j. ejcdt.2013.05.008

Kim, J., \& Kim, J. D. (2008). Inhibitory effect of algal extracts on mycelial growth of the tomato-wilt pathogen, Fusarium oxysporum f. sp. lycopersici. Mycobiology, 36(4), 242-248. https://doi.org/10.4489/ MYCO.2008.36.4.242

Kulasooriya, S. (2011). Cyanobacteria: pioneers of planet earth. Ceylon Journal of Science, 40(2), 71-88. http://dx.doi.org/10.4038/cjsbs. v40i2.3925

Loo, Y. Y., Rukayadi, Y., Nor-Khaizura, M. A., Kuan, C. H., Chieng, B. W. Nishibuchi, M., \& Radu, S. (2018). In Vitro antimicrobial activity of green synthesized silver nanoparticles against selected gramnegative foodborne pathogens. Frontiers in Microbiology, 9, 1555. https://doi.org/10.3389/fmicb.2018.01555

Mazur-Marzec, H., Fidor, A., Cegłowska, M., Wieczerzak, E., Kropidłowska, M., Goua, M., Macaskill, J., \& Edwards, C. (2018). Cyanopeptolins with trypsin and chymotrypsin inhibitory activity from the cyanobacterium Nostoc edaphicum CCNP1411. Marine Drugs, 16(7), 220. https://doi.org/10.3390/md16070220

McNicholl, B. P., McGrath, J. W., \& Quinn, J. P. (2007). Development and application of a resazurin-based biomass activity test for activated sludge plant management. Water Research, 41(1), 127-133. https:// doi.org/10.1016/i.watres.2006.10.002

Mendes, L. B. B., \& Vermelho, A. B. (2013). Allelopathy as a potential strategy to improve microalgae cultivation. Biotechnol Biofue/s, 6(1), 1-14. https://doi.org/10.1186/1754-6834-6-152

Moore R. E. (1996). Cyclic peptides and depsipeptides from cyanobacteria: a review. Journal of Industrial Microbiology, 16(2), 134-143. https:// doi.org/10.1007/BF01570074

Mundt, S., Kreitlow, S., Nowotny, A., \& Effmert, U. (2001). Biochemical and pharmacological investigations of selected cyanobacteria. International Journal of Hygiene and Environmental Health, 203(4) 327-334. https://doi.org/10.1078/1438-4639-00045

Nagatsu, A., Kajitani, H., \& Sakakibara, J. J. T. L. (1995). Muscoride A: A new oxazole peptide alkaloid from freshwater cyanobacterium Nostoc muscorum. Tetrahedron Letters, 36(23), 4097-4100. https:// doi.org/10.1016/0040-4039(95)00724-Q

Nowruzi, B., Khavari-Nejad, R.-A., Sivonen, K., Kazemi, B., Najafi, F., \& Nejadsattari, T. (2012). Identification and toxigenic potential of a Nostoc sp. Algae, 27(4), 303. https://doi.org/10.4490/ algae.2012.27.4.303

Parmar, A., Singh, N. K., Pandey, A., Gnansounou, E., \& Madamwar, D. (2011). Cyanobacteria and microalgae: a positive prospect for biofuels. Bioresource Technology, 102(22), 10163-10172. https:// doi.org/10.1016/j.biortech.2011.08.030

Ploutno, A., \& Carmeli, S. (2000). Nostocyclyne A, a novel antimicrobial cyclophane from the cyanobacterium Nostoc sp. Journal of Natural Products, 63(11), 1524-1526. https://doi.org/10.1021/np0002334 
Potts, M. (1999). Mechanisms of desiccation tolerance in cyanobacteria. European Journal of Phycology, 34(4), 319-328. https://doi.org/10.1 080/09670269910001736382

Priya, H., Prasanna, R., Ramakrishnan, B., Bidyarani, N., Babu, S., Thapa, S., \& Renuka, N. (2015). Influence of cyanobacterial inoculation on the culturable microbiome and growth of rice. Microbiological Research, 171, 78-89. https://doi.org/10.1016/j.micres.2014.12.011

Řezanka, T., \& Dembitsky, V. M. (2006). Metabolites produced by cyanobacteria belonging to several species of the familyNostocaceae. Folia Microbiologica, 51(3), 159-182. https://doi.org/10.1007/ BF02932119

Rippka, R., Waterbury, J. B., \& Stanier, R. Y. (1981). Isolation and Purification of Cyanobacteria: Some General Principles. In M. P. Starr, H. Stolp, H. G. Trüper, A. Balows, \& H. G. Schlegel (Eds.), The Prokaryotes. Springer, Berlin, Heidelberg. https://doi.org/10.1007/9783-662-13187-9 8

Saadatnia, H., \& Riahi, H. (2009). Cyanobacteria from paddy fields in Iran as a biofertilizer in rice plants. Plant Soil and Environment, 55(5), 207-212. https://doi.org/10.17221/384-PSE

Scherer, S., \& Potts, M. (1989). Novel water stress protein from a desiccation-tolerant cyanobacterium. Purification and partial characterization. Journal of Biological Chemistry, 264(21), 12546-
12553. https://doi.org/10.1016/S0021-9258(18)63891-8

Scherer, S., Chen, T. W., \& Böger, P. (1988). A New UV-A/B Protecting Pigment in the Terrestrial Cyanobacterium Nostoc commune. Plant Physiology, 88(4), 1055-1057. https://doi org/10.1104/pp.88.4.1055

Shariatmadari, Z., Riahi, H., \& Shokravi, S. (2011). Study of soil blue-green algae and their effect on seed germination and plant growth of vegetable crops. Rostaniha, 12(2), 101- 110.

Sharma, B. K. (1981). Spectroscopy: Krishna Prakashan Media. India.

Singh, J. S. (2014). Cyanobacteria: a vital bio-agent in eco-restoration of degraded lands and sustainable agriculture. Climate Change Environmental Sustainability, 2(2), 133-137.

Wayne, P. (2012). Clinical and Laboratory Standards Institute (CLSI). Performance standards for antimicrobial susceptibility testing. Twenty-second informational supplement. Document M100-S22.

Win, T. T., Barone, G. D., Secundo, F., \& Fu, P. (2018). Algal biofertilizers and plant growth stimulants for sustainable agriculture. Industrial Biotechnology, 14(4), 203-211.

Zainin, N., Lau, K., Zakaria, M., Son, R., Razis, A. A., \& Rukayadi, Y. (2013). Antibacterial activity of Boesenbergia rotunda (L.) Mansf. A. extract against Escherichia coli. International Food Research Journal, 20(6), 3319-3323 